\title{
Globalisasi Dan Dakwah Islam Kontemporer
}

\author{
Hidayat HT \\ Universitas Islam Negeri Raden Fatah Palembang \\ hidayat_uin@radenfatah.ac.id
}

\begin{abstract}
Globalization is recognized as consciously carrying two sides of values for human life, namely good values and bad values. These two sides of value penetrate into all aspects of the order of life. Consequently, globalization raises many problems that plague the inhabitants of planet earth today. Among the impacts of globalization are the emergence of contemporary issues related to religion as well as challenges for Islamic da'wah, such as: religious pluralism, liberal Islam (religious liberalism), radicalism-terrorism and so on. Islam and its people who are in a global vortex and are related to several contemporary issues should come to the surface with contemporary Islamic ideas or thoughts to answer the challenge of da'wah while positioning Islam as a universal religion. Contemporary Islamic thought is thought that is able to bridge between the two poles, namely between tradition and modernity (al-turats wa al-hadatsah), so that it raises new awareness in giving birth to ideas that can respond to contemporary problems. Preaching contemporary Islamic thought like this is essentially continuing the missionary task that Allah and His Messenger ordered.
\end{abstract}

Keywords: Globalization, Da'wah, Contemporary Islam

\begin{abstract}
ABSTRAK
Globalisasi diakui secara sadar mengusung dua sisi nilai bagi kehidupan manusia yaitu nilai baik dan nilai buruk. Dua sisi nilai ini merambah ke semua aspek tatanan kehidupan. Konsekuensinya globalisasi memunculkan banyak problem yang melanda penghuni planet bumi hari ini. Di antara dampak globalisasi munculnya isu-isu kontemporer yang berhubungan dengan keagamaan sekaligus sebagai tantangan bagi dakwah Islam, seperti: Prulalisme agama, Islam liberal (liberalisme agama), radikalisme-terorisme dan sebagainya. Islam dan umatnya yang berada dalam pusaran arus global dan terkait dengan beberapa persoalan kontemporer tersebut sepatutnya tampil ke permukaan dengan gagasan atau pemikiran Islam kontemporer untuk menjawab tantangan dakwah sekaligus memposisikan Islam sebagai agama yang universal. Pemikiran Islam kontemporer adalah pemikiran yang mampu menjembatani antara dua kutub yakni antara tradisi dan modernitas (al-turats wa al-hadatsah), sehingga memunculkan kesadaran baru dalam melahirkan gagasan yang dapat merespon problematika kekinian. Mendakwahkan pemikiran Islam kontemporer seperti ini hakikatnya melanjutkan tugas kerisalahan yang diperintahkan Allah dan Rasul-Nya.
\end{abstract}

Kata Kunci : Globalisasi, Dakwah, Islam Kontemporer

\section{PENDAHULUAN}

Jika ditelusuri lebih jauh, globalisasi sudah terjadi sejak lama. Dengan kata lain globalisasi tidak bisa dikatakan sebagai gejala baru. Namun, tatkala ditemukan kemajuan teknologi dalam bidang transportasi, komunikasi dan informasi akhir abad 19 
atau abad 20 awal, maka globalisasi ini menjadi kian populer di abad ini atau booming. Apalagi dengan layanan fasilitas teknologi komunikasi dan informasi yang super canggih seperti jaringan internet, whatsap, handphone, zoom dan media sosial lainnya, manusia seakan tinggal di sebuah kampung yang kecil ( global village).

Sebagai dampak canggihnya perkembangan teknologi dan pesatnya ilmu pengetahuan, maka dipastikan globalisasi akan berpengaruh dalam segala sendi kehidupan manusia, termasuk dalam hal ini yang terkait dengan aspek keyakinan atau keagamaan. Di satu sisi globalisasi akan memunculkan berbagai persoalan yang harus dicarikan solusinya, tetapi disi lain ia bisa menjadi peluang untuk dimanfaatkan bagi kemaslahatan bagi penghuni planet bumi ini.

Di tengah kepungan era globalisasi ada dua kemungkinan yang terjadi dengan nilai-nilai agama. Pertama, nilai-nilai agama yang universal akan terus berkembang dan tetap eksis. Ini dimaknai bahwa kemajuan teknologi dalam bidang transportasi, komunikasi dan informasi justru dapat di manfaatkan untuk menjadi wasilah (media) yang merekatkan antar agama-agama, sehingga nilai-nilai kebaikan semua agama menjadi landasan membangun peradaban dunia. Bahkan dalam konteks Islam justru dakwah nilai-nilai kebaikan dan kebenaran akan lebih luas dan leluasa disampaikan dengan pemanfaatan teknologi informasi di era ini. Kemungkinan kedua yang terjadi dengan agama adalah agama akan kehilangan identitas atau nilai-nilainya menjadi krisis. Dengan munculnya nilai-nilai baru yang diusung globalisasi, maka nilai-nilai agama yang selama ini diyakini dan mengikat sebuah masyarakat sejak lama menjadi longgar bahkan terancam sekaligus dipertanyakan.

Berangkat dari peluang dan tantangan di atas, maka Islam sebagai agama yang universal, syamil dan kamil harus mampu dihadirkan dalam rangka memberikan solusi terhadap pelbagai persoalan-persoalan yang muncul di era kontemporer ini.

\section{HASIL DAN PEMBAHASAN}

\section{Globalisasi dan pengaruhnya}

Beberapa ahli mengemukakan beberapa makna tentang globalisasi. Di antaranya Gidden menyebutkan bahwa globalisasi sebuah proses saling keterkaitan antar manusia, antar bangsa yang membuat mennyempitnya batas suatu negara. Interaksi terjadi melalui semua saluran seperti budaya, pariwisata perdagangan dan sebagainya. Dalam pendapat yang tidak jauh berbeda Waters menyatakan globalisasi merupakan 
sebuah proses sosial yang mengakibatkan batas geografis dari suatu negara menjadi kurang penting, terkait dengan kondisi sosial budaya yang akhirnya menjelma ke dalam kesadaran seseorang. ${ }^{1}$

Dari beberapa pandangan pakar di atas, maka dapat dipahami bahwa globalisasi adalah sebuah perubahan dunia sebagai dampak kemajuan kotemporer. Dunia menjadi tanpa sekat, lebih terbuka dan saling ketergantungan. Sehingga semuanya seakan satu dunia atau dengan konsep pandangaan "dunia tanpa batas". Hal ini dipicu oleh kemajuan teknologi, percepatan dan kemudahan transportasi, dan akses ilmu pengetahuan yang sekarang jauh lebih intensif daripada generasi sebelumnya.

Kemajuan bidang teknologi komunikasi dan informasi dapat dikatakan sebagai awal yang menandai proses penggerak perkembangan globalisasi. Namun kemudian ia menjadi pemicu perubahan pada aspek-aspek yang lain seperti aspek sosial, budaya, ekonomi, politik dan termasuk aspek agama. Secara realitas dapat disaksikan bahwa dengan kecanggihan teknologi informasi seperti parabola, internet dan televisi orang dapat melihat dan mengakses informasi, tontonan atau berita secara cepat dari negara yang jauh sekalipun. Sehingga dengan demikian akan terjadi proses saling mempengaruhi secara cepat pula antar negara yang berbeda, sebagai hasil interaksi dunia global. Prilaku dan budaya di dunia barat menjadi trend di belahan dunia timur. Generasi muda akan mengikuti model berpakaian, style rambut, nyanyian yang sedang hit meskipun belum tentu sesuai dengan budaya negerinya sendiri. Tidak luput terjadinya pergeseran budaya atau nilai kearifan lokal suatu masyarakat, misalnya budaya gotong royong, tradisi ritual agama masyarakat, shilaturrahim keluarga dan lainlain..

Baiquni menyebutkan sudah pasti terjadi gesekan dan perubahan budaya sebagai akibat tatanan dan gaya kehidupan masyarakat industrial sebagaimana yang digambarkan di atas. Sebagai contoh dalam masyarakat indutrial tenaga mesin menjadi lebih diutamakan demi efiensi cost dan efektifitas waktu. Tentu sangat betrbeda dengan cara hidup masyarakat agraris selama ini yang cenderung santai dan memanfaatkan tenaga manusia dan hewan. Begitu pula halnya dengan aktifitas para wanitanya yang diberikan kebebasan untuk berekspresi di wilayah publik, serta keleluasaan menggunakan alat transportasi dan sarana komunikasi. Hal ini jauh bergeser

\footnotetext{
${ }^{1}$ Lihat A.Giddens, The Consequences of Modernity. Cambridge: Polity Press, 1990., M.Waters. Globalization. 2ndEdition, Taylor and Francis Group. London, 1995
} 
dari peran wanita yang sebelumnya yang lebih dominan di wilayah domestik dengan mengurus anak, suami dan keluarga. Dengan demikian pergeseran tersebut menjadi sesuatu yang tidak bisa dielakkan. Hanya pondasi dan pemahaman agama yang baik menjadi semacam filter untuk memilah dan memilih norma, nilai dan budaya yang sejalan dengan syariat agama yang dianutnya. ${ }^{2}$

Sebagian orang menyadari sepenuhnya bahwa globalisasi di satu sisi mengusung sesuatu yang positif bagi kehidupan. Dengan kecanggihan transportasi dan komunikasi memudahkan manusia dalam menjalankan aktivitasnya. Manusia didorong mempunyai pemikiran yang rasional dan punya visi ke depan. Pemikiran irrasional lambat laun akan tercampakkan. Tapi di sisi lain globalisasi membawa dampak negatif yang tidak sedikit, terutama jika dikaitkan dalam konteks kehidupan masyarakat melayu Nusantara. Terjadinya penurunan kualitas moral atau degradasi nilai. Hal ini terlihat dengan munculnya penyimpangan prilaku yang berseberangan dengan norma, adat dan nilainilai agama yang menjadi bagian hidup masyarakat melayu. Sebagai contoh memudarnya kesantunan, murahnya nilai nyawa seseorang dengan dibunuh, rendahnya penghormatan pada kaum wanita dengan pelecehan seksual dan asusila lainnya Ironisnya, penyimpangan prilaku ini terjadi di kalangan pemuda sebagai generasi penerus bangsa. Tingginya angka kriminal dengan tawuran, penyalahgunaan narkoba dan zat adiktif lainnya, seks menyimpang atau LGBT. Globalisasi juga melahirkan gaya dan sikap hidup yang membahayakan seperti gaya hidup hedonistik, konsumtif, egois atau individualistik, gaya hidup kebarat-baratan dan sebagainya.

Tentu tidak dapat dielakkan jika kemudian lahir dualisme pandangan dalam menyikapi kehadiran globalisasi. Di satu pihak yang berangkat dari pandangan bahwa globalisasi membawa nilai-nilai yang banyak bertentangan dengan karakter, budaya, moral bangsa bahkan merusak ajaran agama. Dengan dasar ini globalisasi harus ditolak sejauh-jauhnya. Akan tetapi, dipihak yang lain berpandangan bahwa tidak ada persoalan dengan globalisasi. Bagi kelompok ini globalisasi sebagai sebuah berkah, sehingga mereka menutup mata dengan sisi negatif yang diusungnya. Maka kemudian kelompok ini akan menerima globalisasi itu secara total tanpa prasangka sedikitpun.

Kehidupan modern dengan segala kemajuan teknologi dan pesatnya perkembangan ilmu pengetahuan yang diharapkan melahirkan kedamaian dan

2 Achmad Baiquni, Al-Qur'an; Ilmu Pengetahuan dan Teknologi (Yogyakarta: Dana Bhakti Prima Yasa, 1995), h. 154 
kebahagian bagi manusia, nyatanya tidak mampu memberikan ketentraman hidup yang dicita-citakan manusia. Bahkan yang terjadi adalah manusia kehilangan arah dan kehidupan bermakna. Manusia di era ini banyak dihinggapi gangguan kejiwaan seperti depresi, stress, cemas dan merasa terasing (alienasi) meskipun dalam keramaian. Semua ini muncul sebagai akibat krisis spritual dan lenyapnya visi ketuhanan sebagai aspek transendental. Di antara ahli menyebutkan bahwa banyak orang modern menderita existensial vacuun (kehampaan hidup) yang diakibatkan oleh rasa hidup tak bermakna. ${ }^{3}$

Di satu sisi manusia tidak memiliki waktu yang cukup untuk merenungi dirinya dalam upaya merapatkan dirinya pada Tuhannya (hablumminallah). Hal ini dipacu oleh kesibukan dan aturan yang diciptakannya sendiri. makna hidupnya. Di sisi yang lain manusia juga tidak mampu menjalin interaksi dengan sesama makhluk (hablumminannas) Manusia menjadikan dirinya egois dan mengedepankan hidup yang individualistik. Selanjutnya kondisi ini diperparah ketika manusia tidak mampu membangun hubungan baiknya dengan alam semesta (hablumminal'alam). Sehingga yang terjadi kemudian pengrusakan hutan, lingkungan dan alam sekitarnya. Jika kondisi sudah terjadi sedemikian parah, maka manusia akan kehilangan segala-galanya.

Akibat dari cara kehidupan yang digambarkan di atas, manusia dalam semua lapisan baik di pedesaan maupun yang hidup di perkotaan akan dihinggapi kekeringan atau krisis spritual. Oleh karena itu, pada keadaan seperti ini agama dan nilai-nilai yang terkandung di dalamnya menjadi sebuah solusi. Secara lebih khusus, ilmu-ilmu pengetahuan Islam dan ajarannya sepatutnya mampu dikemas sedemikian rupa untuk menjadi rujukan dan solusi alternatif yang diyakini mampu memberikan jalan keluar dari kemelut problem kemanusiaan di era globalisasi ini. Artinya globalisasi bukan hanya terkait dengan urusan pesatnya informasi dan canggihnya informasi semata, namun menyentuh semua bidang kehidupan manusia seperti: politik, sosial, budaya, dan isu-isu keagamaan.

\section{Isu-isu kontemporer sebagai tantangan dakwah}

Seiring dengan kencangnya arus globalisasi yang masuk ke semua penjuru dunia dan mempengaruhi semua aspek tatanan kehidupan manusia, maka konsekuensinya memunculkan banyak problem yang melanda manusia hari ini. Di antara beberapa isu

\footnotetext{
${ }^{3}$ Ali Maksum, Tasawuf Sebagai Pembebasan Manusia Moderen: Telaah Signifikansi Konsep Tradisionalisme Sayyid Husein Nasr, (Surabaya: Pustaka Pelajar, 2002), h. 4
} 
kontemporer yang berkaitan dengan keagamaan sekaligus sebagai tantagan bagi dakwah Islam akan dibentangkan dalam tulisan ini antara lain yaitu: Prulalisme Agama, Islam Liberal (Liberalisme Agama) dan Terorisme-radikalisme.

\section{a. Prulalisme Agama}

Secara etimologis, pluralisme agama berasal dari dua kata, yaitu "pluralisme" dan "agama”. Dalam bahasa Arab "al-ta'addudiyyah al-diniyyah" dan dalam bahasa Inggris "religious pluralis". Oleh karena istilah pluralisme agama berasal dari bahasa Inggris, maka untuk mendefinisiskannya secara akurat harus merujuk pada kamus bahasa Inggris tersebut. ${ }^{4}$ Secara harfiah pluralisme berarti jamak, beberapa, berbagai hal atau banyak. ${ }^{5}$ Definisi pluralisme adalah suatu kerangka interaksi tempat setiap kelompok menampilkan rasa hormat dan toleransi satu sama lain, berintraksi tanpa konflik. ${ }^{6}$

Sejatinya konsep pluralisme ( $t a$ 'addudiyah) tidak populer dalam kajian ulama dan pemikir Islam terdahulu. Tetapi tidak populernya terminologi tersebut bukan bermakna bahwa tema-tema prulalitas tidak diungkap al-Quran dan hadits. Justru wacana ini banyak diungkap dalam sumber-sumber ajaran Islam sehingga turut menjadi perhatian yang dikaji para ulama.

Hanya saja aktualisasi nilai-nilai prulalitas atau prulalisme yang dikedepankan adalah dalam aspek-aspek sosial (ijtima'iyyah). Misalnya dalam menerapkan aturan hubungan antar individu, antar kelompok sehingga terjalin suatu interaksi dengan baik dalam menjalankan hak dan kewajiban masing-masing. Termasuk pengakuan terhadap adanya ragam dalam suku, ras dan agama. Ini diorientasikan dalam mencapai kedamaian bersama dalam satu komunitas. Artinya pluralisme tidak diorientasikan atau diarahkan dalam aspek yang menyangkut keyakinan ketuhanan atau teologis. Dengan kata lain tidak dimaknai kesamaan dalam keyakinan dan ibadah, karena dalam ajaran Islam segala sesuatu yang terkait dengan keyakinan dan pengabdian merupakan sesuatu yang sudah qoth'i dan tegas. Semua manusia diberikan kebebasan menjalankan keyakinannya, dan tidak dibolehkan satu komunitas melakukan pemaksanaan terhadap kelompok yang lain. Secara tegas misalnya dalam QS. al-Kafirun: 109: 6 memberikan arahan : "Untukmu agamamu dan untukku agamaku”. Dalam ayat yang lain QS. Al

\footnotetext{
${ }^{4}$ Anis Malik Thoha, Tren Pluralisme Agama, Tinjauan Kritis Cet.I, (Jakarta:Gema Insani , 2005), h. 11

5 Tim Penyusun Kamus Pusat Pembinaan dan Pengembangan Bahasa, Kamus Besar Bahasa Indonesia, (Jakarta: Balai Pustaka, 1995) h. 691

${ }^{6}$ Imam Subkhan, Hiruk Pikuk Wacana Pluralisme di Yogya, (Yogyakarta: Kanisius, 2007), h. 28
} 
Baqarah: 2: 256 disebutkan artinya : "Tidak ada paksaan untuk (memasuki) agama (Islam); sesungguhnya telah jelas jalan yang benar dari pada jalan yang sesat. Karena itu barang siapa yang ingkar kepada thaghut dan beriman kepada Allah, maka sesungguhnya ia telah berpegang kepada buhul tali yang amat kuat yang tidak akan putus. Dan Allah Maha Mendengar lagi Maha Mengetahui”.

Menurut Bryne bahwa pluralisme agama lebih mengarah pada kesatuan agama dalam menuju pada satu Tuhan. Ia menegaskan agama apapun adalah keselamatan. Semua agama mengajarkan hal yang sama dalam mengakui Tuhan sebagai kebenaran Mutlak. ${ }^{7}$ Jika dimaknai pemahamna seperti ini sangat bersesuaian dengan pemahaman relativitas. Semua menjadi benar, tidak ada yang paling benar.

Berangkat dari sini dapat dikatakan bahwa antara pemahaman Islam dengan teori atau wacana pluralisme agama yang digaungkan hari ini adalah sesuatu yang bertentangan. Islam menganggap bahwa pluralisme adalah keniscayaan yang tidak mungkin dihindari. Sedangkan teori-teori pluralisme agama memandang pluralisme adalah perbedaan yang tidak hakiki. Dengan demikian persoalan mendasar yang muncul kemudian ketika pemahaman seperti ini dibawa dalam aspek keyakinan, karena akan dimaknai tidak ada perbedaan secara hakiki dalam agama yang berbeda, atau dengan kata lain hakikat semua agama menjadi sama. Artinya Islam memandang pluralisme itu sesuatu yang sifatnya sosiologis sementara dipihak lain memandang pluralisme merambah pada aspek teologis.

Untuk itu perlu ditegaskan bahwa tidak sama antara pluralitas agama-agama dengan pluralisme agama. Gagasan prulalisme agama menjadikan kebenaran dalam suatu agama tidak bersifat mutlak (kebenaran relatif). Sedangkan prulalitas agama merupakan pengakuan yang tidak bisa dinafikan bahwa di atas muka bumi ini terdapat banyak agama dan keyakinan yang dianut manusia. Bahkan dalam konteks ini, Islam mengajarkan kepada pemeluknya bahwa keragaman itu sebuah sunnatullah dan bukti keagungan-Nya. Sebagai contoh dalam surat al-Maidah ayat 48 disebutkan:

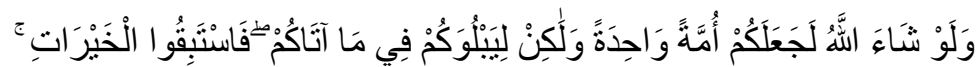

"Sekiranya Allah menghendaki, niscaya kamu dijadikan-Nya satu umat (saja), tetapi Allah hendak menguji kamu terhadap pemberian-Nya kepadamu, maka berlomba-lombalah berbuat kebajikan."

\footnotetext{
${ }^{7}$ Peter. Bryne, Prolegomena to Religious Pluralism, (London: Macmillan Press Ltd., 1995), h. vii
} 
Pluralisme agama dalam artian "keyakinan yang tidak mutlak" akan kebenaran ajaran agamanya, disertai "keraguan yang juga tidak mutlak" terhadap ketidakbenaran agama yang lain. Penganut konsep ini, tidak yakin sepenuhnya bahwa agamanya benar, sebagaimana ia juga tidak benar-benar yakin bahwa agama lain salah. Sebab, menurut pandangan mereka, persoalan tentang kebenaran dan ketidakbenaran sebuah agama secara mutlak hanya akan dapat diketahui kelak di akhirat. Walaupun mereka sebenarnya selalu berada dalam posisi ragu-ragu, namun karena keimanan yang maksimal hanya akan dicapai jika seorang penganut agama meyakini sepenuhnya kebenaran agamanya. Maka, penganut agama ini senantiasa berada dalam posisi "berpura-pura" untuk yakin atas kebenaran agamanya dan ketidakbenaran agama yang lain.

Islam menolak gagasan pluralisme agama seperti di atas. Dalam konteks Indonesia, MUI (Majelis Ulama Indonesia) pada Munas tahun 2005 bahkan pernah menerbitkan fatwa mengenai pemikiran-pemikiran yang menyimpang, diantaranya adalah prulalisme. Pluralisme agama dianggap tidak sejalan dengan ajaran Islam. MUI menegaskan bahwa dalam hal-hal yang berkaitan dengan urusan keyakinan (aqidah) dan ibadah, seorang muslim harus punya pandangan bahwa Islam adalah agama yang benar. Artinya dalam hal ini Islam dan muslim adalah eksklusif. Dan ini tidak berarti mengajarkan bahwa ekslusifitas juga dalam hal kemanusian dan hubungan dengan agama lain. Artinya Islam dan pemeluknya sangat inklusif, terbuka, damai dalam menerima kemajemukan (prulalitas) agama-agama.

Penyebaran paham pluralisme agama di tengah masyarakat muslim dapat dilihat sebagai bagian dari upaya Barat dalam mengglobalkan nilai-nilainya, meneguhkan hegemoninya, bahkan dipahami sebagai upaya kalangan misionaris Kristen untuk melemahkan kayakinan kaum Muslim. Pluralisme, sebagaimana sekularisme adalah sejenis "senjata pemusnah masal" terhadap keyakinan fundamental agama-agama. ${ }^{8}$ Inti doktrinnya adalah untuk menghilangkan sifat eksklusif umat beragama, khususnya Islam. Artinya dengan paham ini umat Islam diharapkan tidak lagi bersikap fanatik, merasa benar sendiri dan menganggap agama lain salah. Menurut John Hick, di antara prinsip pluralisme agama menyatakan bahwa agama lain adalah sama-sama jalan yang benar menuju kebenaran yang sama (Other religions are equally valid ways to the same

\footnotetext{
${ }^{8}$ Adian. Husaini, Liberalisasi Islam di Indonesia; Fakta dan Data, (T.K: Dewan Da'wah Islamiah Indonesia. 2007), h. 346
} 
truth). ${ }^{9}$ Prinsip ini kemudian diamini oleh Abdul Munir Mulkhan, dosen UIN Yogyakarta, yang menulis: "Jika semua agama memang benar sendiri, penting diyakini bahwa surga Tuhan yang satu itu sendiri terdiri banyak pintu dan kamar. Tiap pintu adalah jalan pemeluk tiap agama memasuki kamar surganya. Syarat memasuki surga ialah keikhlasan pembebasan manusia dari kelaparan, penderitaan, kekerasan dan ketakutan, tanpa melihat agamanya. Dari sini kerjasama dan dialog pemeluk berbeda agama jadi mungkin." 10

Di Indonesia ide pluralisme agama sering disebut ide inklusivisme. Ini bermakna kesiapan seseorang untuk menerima kebenaran agama selain dari keyakinan yang dianutnya. Keselamatan hakiki bisa diperoleh dari agama apapun. Jika makna kata "Islam" sering diartikan sebagai ketundukan dan penyerahan totalitas pada Tuhan, maka seorang yang di luar Islam pun bisa dikatakan muslim jika ia tunduk dan pasrah pada Tuhannya.

Sebagai contoh, pengusung ide-ide ini sering mengatakan bahwa Islam bukanlah satu-satunya agama yang benar. Semuanya berhak masuk surga. Mantan Koordinator Jaringan Islam Liberal Ulil Abshar Abdalla mengatakan:

"Semua agama sama. Semuanya menuju jalan kebenaran.Jadi, Islam bukan yang paling benar." "11 "Dengan tanpa rasa sungkan dan kikuk saya mengatakan, semua agama adalah tepat berada pada jalan seperti itu, jalan panjang menujuYang Maha benar. Semua agama dengan demikian adalah benar, dengan variasi, tingkat dan kadar kedalaman yang berbeda-beda dalam menghayati jalan religiusitas itu. Semua agama ada dalam satu keluarga besar yang sama: yaitu keluarga pencinta jalan menuju kebenaran yang tak pernah ada ujungnya.,"12

Contoh lain seperti yang diungkapkan Dawam Rahardjo, seorang tokoh Muhammadiyah Indonesia yang membela keberadaan kelompok Ahmadiyah di Indonesia. Ia mengatakan:

"Ahmadiyah sama dengan kita...Jadi kita tidak bisa menyalahkan atau membantah akidah mereka, apapun akidah mereka itu. Kita menyangka akidah mereka menyimpang. Misalnya, mereka percaya kalau Mirza Ghulam Ahmad adalah Nabi. Tapi kalau sudah menjadi kepercayaan mereka, mau apa? Itu 'kan soal kepercayaan. Itu 'kan sama saja dengan kita percaya pada Nabi Muhammad SAW.",13

\footnotetext{
${ }^{9}$ ISLAMIA, Edisi 3, September-November, 2004

${ }^{10}$ Abdul Munir Mulkhan, Ajaran dan Jalan Kematian Syekh Siti Jenar, (Yogyakarta: Kreasi Wacana, 2002) h. 44

${ }^{11}$ Majalah GATRA, Edisi 21 Desember 2002

${ }^{12}$ Harian Kompas, Edisi 18 November, 2002.

${ }^{13} \mathrm{http}$ ://islamlib.com di akses 17 Januari 2021
} 
Dari beberapa contoh ungkapan tokoh-tokoh Islam Indonesia di atas, maka gagasan pluralisme agama atau konsep inklusif dalam teologi sangat bertentangan dengan nilai-nilai ketauhidan dalam Islam. Misalnya Allah memberikan penegasan dalam fiiman-Nya dalam al-Qur'an pada surat Ali Imran ayat 19 yang artinya:

"Sesungguhnya agama (yang diridhai) di sisi Allah hanyalah Islam"dan" Barangsiapa mencari agama selain agama Islam, maka sekalikali tidak akan diterima (agama itu) darinya, dan dia di akhirat termasuk orang-orang yang rugi.

Dari pijakan pemahanan di atas maka pluralisme agama dipahami sebagai keragaman pemahaman tentang Tuhan yang sama dan satu. Konsep yang mengakui kebenaran semua agama secara mutlak atau menempatkan kebenaran semua agama dalam posisi sejajar. Oleh penganut paham pluralisme jenis ini, agama dinilai sebagai hasil pemahaman manusia tentang eksistensi Tuhan. Agama juga merupakan bentuk ekspresi kepercayaan dan keyakinan akan eksistensi Tuhan. Sehingga jika agama beragam jenisnya, maka itu tak lain dari penangkapan sekaligus pemahaman yang berbeda-beda oleh masing-masing individu atas eksistensi Tuhan yang sebenarnya sama dan satu. Jadi, dalam kerangka konsep pluralisme jenis ini, semua agama diakui kebenarannya. Maka tidak berlebihan kalau ada yang sampai pada pandangan yang menyebutkan bahwa pluralisme agama ini sebagai kesyirikan abad modern.

\section{b. Liberalisme Islam}

Islam liberal merupakan bagian dari gelombang besar liberalisasi agama yang melanda seluruh agama yang ada. Liberalisasi agama merupakan suatu proses menempatkan suatu agama dalam dinamika sejarah, dimana kebenaran dan realitas tidak di atas pengetahuan dan lemah kepercayaan terhadap agama juga wahyu. ${ }^{14}$ Tidak ada agama yang selamat dari perubahan sejarah. Kebenaran mendasar dari agama dipandang hanya sebagai teori-teori, atau sebagai ilusi yang sia-sia. Nilai absolute ditolak dan nilai relatif diafirmasi; tidak ada yang pasti, kecuali kepastian bahwa tidak ada yang pasti. ${ }^{15}$ Sehingga liberalisme agama dapat difahami sebagai kebebasan dalam mengekspresikan nilai-nilai agama yang dilandasi kebebasaran menggunakan akal fikiran manusia. Ini akan menjurus atau berakibat meletakkan doktrin-doktrin agama di

\footnotetext{
14 Syed Muhammad Naquib Al-Attas, Islam and Secularism, (Kuala Lumpur: ISTAC, 1993), h. 171

15 Syed Muhammad Naquib al-Attas, Prolegomena to the Metaphysics of Islam, (Kuala Lumpur: Institut Antarabangsa Pemikiran dan Tamadun Islam, 1995), h.26.
} 
bawah akal manusia, atau setidaknya doktrin agama akan ditolak jika tidak sejalan dengan akal fikiran manusia.

Liberalisasi Islam artinya proses peliberalan Islam atau Islam yang diliberalkan, maksudnya dalam Islam itu harus diubah sesuai dengan perkembangan zaman. Karena sekarang ini yang berkuasa di dunia adalah nilai-nilai liberal atau sekuler yang dibawah oleh peradaban Barat. Maka Islam itu di modifikasi atau disesuaikan dengan nilai-nilai yang mendominasi berlaku saat ini yakni Barat. Islam dipaksa untuk mengikuti Barat yang liberal, itulah yang dimaksud liberalisasi Islam. Jadi aturan-aturan Islam yang mereka anggap tidak sesuai itu harus diubah. Jika dulu misalnya muslimah itu haram hukumnya menikah dengan non muslim, maka sekarang harus diiberalkan menjadi boleh tidak haram. Jika dilarang dianggap melanggar HAM. Agama juga tidak boleh menjadi faktor penghambat dalam perkawinan homo sexual Sekarang harus diubah sesuai dengan perkembangan zaman.

Jika diteropong secara utuh, sesungguhnya gagasan liberalisasi keagamaan sangat erat kaitan dengan pemikiran modern dan postmodernisme yang di kalim sebagai buah dari peradaban Barat. Gerak liberalisme ini diawali kebebasan dalam bidang ekonomi dan politik. Selanjutnya merambah pada kebebasan intelektual dan agama. Dalam Islam ide liberalisasi ini berkembang dengan berbagai metode pendekatan. Misalnya munculnya wacana dekonstruksi syariat, upaya penafisran kembali al-Quran (reinterpretasi al-Quran), mengusung ide relativisme kebenaran dan sebaginya. Pendekatan dan gagasan-gagasan yang dimunculkan tersebut jelas akan menimbulkan efek yang buruk terhadap tatanan masyarakat yang sudah mapan. Ironisnya, dalam konteks ke-Indonesiaan gaung ide-ide Islam liberal ini digawangi cendekiawan dan tokoh-tokoh Islam. Maka sudah menjadi lumrah jika penelitian, pertermuan-pertemuan ilmiah, jurnal, majalah berpartisipasi menjadi corong yang menggemakan gerakan liberalisme pemikiran Islam.

Klaim Barat yang menggangap bahwa pandangan mereka yang universal dan relevan untuk dijadikan pegangan manusia semua di belahan bumi ini, maka kemudian mereka menjajakan, bahkan menanamkan dengan "paksa" ide-idenya dengan memanfaatkan globalisasi ini dengan westernisasi. Dengan kepongahan Barat yang merasa dominan terhadap dunia yang dianggap dibawahnya termasuk dunia Islam, maka dimunculkan terminologi dan slogan-slogan Islam Modern, Islam Liberal, Islam Fundamentalis dan sebagainya. Ini sebagian contoh kecil dari konsep-konsep yang 
disematkan kepada Islam oleh dunia Barat, meskipun terkesan terlalu dipaksakan dalam pembenarannya.

Merebaknya liberalisme Islam ini menjadi satu diantara tantangan eksternal yang dihadapi umat Islam di era kontemporer ini. Menurut Hamid Fahmi Zarkasyi, sebagai agama dengan pemeluk terbesar di dunia, Islam juga tidak lepas dari proses liberalisasi yang tidak lain adalah bagian dari westernisasi atau pembaratan Islam. Dengan diterapkannya liberalisasi Islam, agama ini ditempatkan dalam konteks perubahan sejarah dan dipaksa harus mengikuti perubahan sejarah tersebut. Sehingga disesuaikan dengan ilmu pengetahuan dan kultur manusia modern. Agama berubah menjadi pengalaman keagamaan. ${ }^{16}$ Kalau pemkiran semacam ini diadopsi dalam Islam, maka yang akan terjadi kemudian nilai-nilai kebenaran Islam yang sudah absolut (qoth'i) menjadi diragukan (zhanni). Nilai-nilai agama dipaksa untuk dapat adaptasi dengan nilai-nilai modern. Ukuran sebuah kebenaran dan kesalahan akan ditentukan berdasarkan cara pandang dan persetujuan manusia. Lambat laun manusia akan meragukan agama dan akhirnya meninggal agamanya.

Azizy menyebutkan bahwa kalau cara pandang manusia seperti di atas, maka dipastikan sesuatu yang dianggap absolut akan tersingkir dalam Islam. Gerakan liberalisasi pemikiran keagamaan ini telah menggiring beberapa intelektual Muslim untuk anti nilai-nilai keagamaan. Bahkan dikhawatirkan, jumlah mereka akan semakin bertambah ketika menghadapi era globalisasi. ${ }^{17}$ Oleh karena itu tidak heran jika hari ini yang menggaungkan pendapat-pendapat seperti al-Quran tidak lebih adalah produk budaya bukan wahyu, otentitas al-Quran diragukan, ajaran Islam tidak up to date, syariat Islam menindas kaum wanita dan bias gender, tidak lagi lahir dari lisan pemikiran para orientalis, tapi justru lahir dari tokoh-tokoh atau pemikir Islam sendiri. Inilah apa yang pernah dikemukakan dalam disertasi Greg Barton di Monash University, Australia. Barton menyebutkan beberapa program penting dan utama yang akan diimplematasikan di Indonesia sebagai dukungan program Liberasi Islam. Program-program yang dimaksud yaitu: pentingnya kontekstualisasi ijtihad, komitmen terhadap rasionalitas dan pembaruan, penerimaan terhadap pluralisme sosial dan pluralisme agama-agama, pemisahan agama dari partai politik dan adanya posisi non

\footnotetext{
${ }^{16}$ Hamid Fahmi Zarkasyi, Liberalisasi Pemikiran Islam, Gerakan Bersama Missionaris, Orientalis dan Kolonialis, (Gontor: CIOS-ISID, 2008), h. 33

17 Qodri Azizy, Melawan Globalisasi; Reinterpretasi Ajaran Islam Persiapan SDM dan Terciptanya Masyarakat Madani, (Yogyakarta: Pustaka Pelajar. 2004), h.17
} 
sektarian negara. ${ }^{18}$ Berangkat dari gagasan program Barton ini membuka jendela bagi umat Islam untuk melihat bahwa gagasan dan proyek liberalisasi Islam di Indonesia bukan isapan jempol, tetapi nyata, sedang dan terus berjalan secara sistematis dengan strategi yang matang serta dukungan dana yang memadai.

Menurut Hamid Fahmi Zarkasyi, dalam menyebarkan konsep-konsep, nilai, kultur dan sistem, Barat menggunakan berbagai kendaraan seperti westernisasi dan globalisasi. Sementara orientalisme dimanfaatkan untuk membaca pemikiran Islam dari kaca mata Barat, sehingga melahirkan makna Islam yang berbeda dari pemahaman umat Islam sendiri. Untuk memperluas penerimaan kultur dan kepercayaan Barat, maka digunakanlah misionarisme sebagai sarananya. Adapun kolonialisme digunakan untuk menaklukan dunia Islam dengan memanfaatkan orientalisme dan misionarisme untuk tujuan-tujuan politik dan ekonomi. ${ }^{19}$ Ironisnya dalam konteks Indonesia pemikiran liberal dalam Islam ini justru ini dimotori oleh orang-orang dengan latar belakang studi Islam. Orang-orang yang punya otoritas dalam bidang keislaman. Mereka adalah dosendosen di kampus-kampus Islam atau di lembaga-lembaga Islam lainnya. Jadi orang yang seharusnya menjaga Islam malah merusak Islam.

Dengan otoritas keimuan yang dimiliki, pengusung ide Islam liberal ini meyakinkan umat dengan nash-nash yang telah ditafsirkan berdasarakan nafsu dan akalnya semata. Sehingga tidak heran jika banyak dari umat Islam yang menalan mentah-mentah gagasan tersebut dan mengadopsi serta mempraktekan gagasan yang mereka gaungkan. Di antara contoh ajaran atau syariat Islam yang dirubah berangkat dari tafsirannya yaitu: Penghalalan terhadap hukum nikah meskipun berbeda agama, Merestui penyimpangan seks (LGBT) dengan dalih HAM dan kecocokan masingmasing, Penolakan wajibnya pemakaian jilbab bagi muslimah. Masih banyak lagi penyimpangan ide-ide yang dimunculkan. Padahal jika saja mereka mau jujur sebetulnya syariat yang mereka gugat tersebut sudah menjadi kesepakatan (ijma) jumhur ulama terdahulu dan melawan arus dari tafsiran-tafsiran yang mu'tabarah..

\section{c. Radikalisme dan Terorisme}

Persoalan yang juga menjadi tantangan bagi umat Islam di era global atau kontempore ini adalah radikalisme Islam. Persoalan radikalisme (kekerasan dalam

\footnotetext{
18 Adian (Husaini, Liberalisasi Islam, h. 12

${ }^{19}$ Fahmi Zarkasyi, Liberasi Pemikiran, h. 44
} 
Islam) telah lama memcuat ke permukaan utamanya di kalangan dunia Internasional. Dengan efek dahsyatnya media yang mampu membangun persepsi masyarakat, sehingga isu radikalisme Islam ini menjadi wacana yang kerap menjadi perhatian khusus dunia global. Sehingga kemudian tidak dapat dielakkan terbangun opini besar terutama di Barat bahwa Islam adalah ideologi yang mendorong lahirnya tindakan kekerasan, ekstrimis. militan, fundamentalis, jihadis sampai pada sebutan teroris. Menurut Yusuf al-Qardhawi, faktor utama munculnya radikalisme dalam beragama adalah kurangnya pemahaman yang benar dan mendalam atas esensi ajaran agama Islam itu sendiri dan pemahaman literalistik atas teks-teks agama. ${ }^{20}$

Seiring bubarnya negara Uni Soviet yang dibarengi dengan runtuhnya ideologi komunisme, maka Islam menjadi sesuatu gerakan yang menakutkan bagi negara-negara Barat. Sehingga diberilah pelabelan terhadap Islam sebagai gerakan radikal. Sebutan radikal ini makin menguat ketika lahirnya gerakan-garakan yang menunjukkan anti Amerika Serikat, anti Barat baik yang ditunjukkan masyarakat biasa, maupun yang dimotori oleh tokoh-tokoh besar bahkan pemimpin dunia yang concern terhadap Islam. Dalam pandangan Barat reaksi-reaksi yang ditunjukkan mewakili umat Islam tersebut sebagai sesuatu yang membahayakan bagi dominasi barat selama ini dalam mencengkram dunia Islam.

Terlebih lagi tatkala munculnya gerakan sekelompok umat Islam dengan polapola kekerasan yang juga dilengkapi dengan atribut Islam, maka ini menjadi santapan segar bagi dunia Barat untuk mengeskpos ke seluruh dunia yang menjadi pembenaran terhadap asumsi mereka bahwa Islam adalah agama radikal dan teror. Sehingga umat Islam makin menjadi tertuduh. Dalam konteks Indonesia, dugaan Barat makin menjadi kuat, tatkala aksi teror dan kekerasan dipertontonkan oleh kelompok-kelompok yang mengatasnamakan Islam dengan melakukan pengeboman di beberapa tempat publik, bahkan diikuti dengan bom bunuh diri. Sebut saja misalnya aksi bom malam Natal pada tahun 2000, berlanjut di tahun 2001 di kedutaan Philipina. Tidak lama berselang terjadi tahun 2002 Bom Bali pertama, selanjutnya pengeboman Kedutaan Australia tahun 2004, terjadi lagi untuk kedua kalinya Bom di Bali tahun 2005 dan sebagainya. Aksiaksi ini tentu makin mencitrakan Islam sebagai agama radikal bagi dunia Barat.

\footnotetext{
${ }^{20}$ Yusuf Qardhawi, as-Shahwah al-Islamiyyah bayna al-Juhud wa at-Tatharruf, cet. ke-1, (Kairo: Dar asy-Syuruq. 2001), h. 51-57
} 
Meskipun label Islam radikal dan teror dari Barat itu belum tentu benar dan pelakunya tidak bisa sepenuhnya mengatasnamakan Islam.

Terorisme dianggap sebagai aktualisasi kekinian dari wujud perang peradaban (clash of civilization) yang menjadi jualan Barat sebagai propaganda anti Islam. Tragedi 11 September 2011 serangan gedung kembar World Trade Cantre (WTC) sebagai simbol pusat ekonomi Amerika Serikat makin menjadi pemicu sentimen Barat terhadap Islam. Peristiwa ini menjadi modal bagi Amerika Serikat dan sekutunya untuk menghabisi kelompok-kelompok Islam radikal yang selama ini dipandang menghalangi dominasi Barat. Inilah momentum yang meraka jadikan sebagai alasan pemusnahan terorisme di dunia. Meskipun sampai saat ini tidak ada satu buktipun yang valid dan mampu meyakinkan dunia internasional bahwa pengeboman itu dilakukan oleh kelompok Islam.

Tragedi WTC mendorong perubahan terhadap konstelasi politik global. Amerika Serikat yang merasa menjadi polisi dunia melalui pemimpinnya saat itu George W Bush membuat keputusan yang berdampak global. Amerika Serikat mengajak seluruh dunia terlibat dalam menjadikan terorisme menjadi menjadi musuh bersama. Negara yang tidak terlibat dalam kebijakan AS ini dianggap sebagai musuh AS dan dipandang negara yang mendukung aksi-aksi terorisme. Tentu kebijakan ini akan memberikan dampak sebagai tekanan AS terhadap negara-negara lain termasuk Indonesia.

Dalam pandangan pengamat politik, sebetulnya AS dan Barat menjadikan momentum perang melawan terorisme sebagai alasan untuk menekan dan meletakkan dominasinya terhadap negara-negara muslim yang selama ini menunjukkan sikap anti AS dan Barat. Ironisnya, propaganda Barat memerangi teorisme itu disepakati dan diterima menjadi agenda bersama oleh negara-negara muslim. Bahkan Indonesia sebagai negara yang mayoritas Islam dan terbesar di dunia memberikan respon cepat dengan melahirkan UU anti-terorisme yang memunculkan pro dan kontra. Ini dipandang sebagai upaya dlam mendiskreditkan umat Islam. Sebagai contoh belum lama ini pernyataan kontroversial Jenderal Purn. Fachrurrozi sebagai Menteri Agama yang baru saja diberhentikan, ia menyebutkan teroris terkesan muncul dari pemuda-pemuda berpenampilan baik dan menarik (good looking), yang sholeh, penghafal al-Quran dan yang akrab dengan masjid. Sungguh ini pernyataan yang menyakiti umat Islam dan memancing reaksi berbagai pihak. Apalagi bagi masyarakat muslim yang tinggal di Barat, isu-isu terorisme dan radikalisme ini menjadi tantangan besar dan mengusik 
ketentraman mereka selama ini. Aktivitas keagamaan menjadi terbatas dan dicurigai. Bahkan muncul stigma negatif dalam hubungan sosialnya, seakan seorang muslim identik dengan radikalis dan teroris.

Menurut Yusuf Qardhawi ada beberapa indikator religius extremism. Pertama fanatisme dan intoleransi, sebagai akibat dari prasangka (prejudice), kekakuan (rigidity), dan kepicikan pandangan (lack of insight), kemudian menggiring mereka untuk memaksa orang lain, baik dalam bentuk terorisme intelektual seperti fitnah dan tuduhan penganut bid'ah (mengada- ngada), kafir, fasik (menyimpang), murtad. Kedua, berlebih-lebihan atau melampaui batas, misalnya ada kelompok agama yang cenderung mengambil garis keras (hard-line) dengan berdemonstrasi mengumbar makian, hasutan dan bahkan ancaman. Para penganjur agama kelompok ini mendoktrinasi orang awam dan memanipulasi solidaritas kelompok akibat kedangkalan pemahaman agama. Ketiga membebani orang lain tanpa mempertimbangkan situasi dan kondisi. Keempat keras dalam memperlakukan diri sendiri dan orang lain sehingga asas praduga tak bersalah tidak pernah dihiraukan. Semua ciri ekstremisme agama yang tiranik dan tidak egaliter ini jelas membahayakan hak-hak orang lain. Ektremisme juga melahirkan bahaya dan ketidaknyamanan, serta mencabut rasa aman dan perlindungan.oleh karena itu harus ada paradigma dari sikap beragama yang humanis. Paradigma humanis ini adalah paradigma nilai, sikap, norma, praktik keberagamaan (religiosity) yang mendukung kehidupan tanpa kekerasan dan damai. ${ }^{21}$

Oleh karena itu, tugas berat dan tanggung jawab besar yang harus dilakukan tokoh dan para ulama terhadap umat beragama agar membangun kesadaran ilmiah dalam rangka meluruskan sejarah ke seluruh masyarakat dunia bahwa agama khusunya Islam tidak ada hubungan dengan radilkalisme dan terorisme. Artinya jika tindakan teror dan kekerasan yang dilakukan oleh orang yang menganut suatu agama tertentu, tidak seharusnya serta merta agama yang dianutnya dikaitkan dengan aksi terorisme.

Di Barat juga secara umum dalam merespon aksi radikalisme dan terorisme tidak sama. Setidaknya terbagi dalam dua kelompok menyikapi persoalan tersebut. Kelompok pertama yang selalu mengarahkan tuduhannya kepada Islam setiap kali terjadi tindakan terorisme. Bagi kelompok ini agama selalu punya stigma negatif. Agama menjadi biang atau sebab terjadinya kerusakan dan kehancuran yang ditimulkan aksi teroris dan radikal. Maka kemudian efek taruma ini melahirkan sikap kebencian

\footnotetext{
${ }^{21}$ Lihat Yusuf Qardhawi, al-Sahwah al-Islamiyyah, , h. 23-29
} 
pada suatu agama, terjadi konversi (pindah) agama, bahkan anti atau tidak menganut agama apapun. Kelompok kedua yang memiliki kedewasaan dan wawasan luas dalam menyikapi persoalan, sehingga mereka lebih arif dan fair. Mereka berpandangan bahwa perilaku teror dapat terjadi dibelahan dunia manapun, bisa dilakukan oleh aktor yang dari penganut agama apapun. Esposito menyebutkan bahwa walaupun faktorfaktor munculnya radikalisme beragama sangat kompleks dan beragam, namun peperangan dan kekerasan dalam agama selalu bermula dari faktor keimananan manusia. $^{22}$

Efek bagi golongan kedua ini melahirkan semangat untuk kembali pada agama dan memahami doktrin-doktrin agama lebih dalam.Mereka bahkan mulai tertarik untuk mengetahui apa itu agama. Di tengah komunitas inipun bisa lahir pikiran-pikiran kritis yang menyoroti kebijakan perintah dalam menyikapi radikalisme dan terorisme. Sebagai contoh di AS sendiri muncul reaksi penolakan terhadap kebijakan pemerintahnya yang melakukan serangan dan campur tangan terhadap beberapa negara di Timur Tengah, karena perilaku dominasi seperti itu dianggap sebagai bagian dari perilaku teror.

Setiap aksi teror dan kekerasan adalah sesuatu yang membahayakan dan mengancam keselamatan orang lain. Perilaku yang memunculkan sentimen perpecahan umat beragama, menciptakan kondisi dunia yang chaos seperti ini tidak bisa ditolelir, apalagi jika dilakukan atas nama ideologi keagamaan. Pada kelompok-kelompok ekstrim, pemahaman teologis yang parsial dan menyimpang mendorong tindakan kekerasan untuk mencapai tujuan yang dianggap benar. Agama bisa dijadikan alat pembenar atau melegimitasi tindakan kekerasan dan terorisme. Menurut Arkoun, alQur'an telah digunakan muslim untuk mengabsahkan perilaku, menjustifikasi tindakan peperangan, melandasi berbagai apresiasi, memelihara berbagai harapan, dan memperkukuh identitas kolektif. ${ }^{23}$

Dalam keyakinan kelompok-kelompok ekstrem ini teror dan kekerasan harus dilakukan demi mencapai kondisi ideal menurut ideologinya sendiri. Dilandasi dari sikap keberagamaan moderat (wasathiyah) yang dapat mengendalikan sikap ekstrem

\footnotetext{
${ }^{22}$ John L. Esposito, Unholy War: Teror atas Nama Islam, (Yogyakarta: Ikon. 2003), h..30
}

${ }^{23}$ Mohammed Arkoun, Berbagai Pembacaan al-Qur'an, terj. Machasin, Jakarta: INIS. 1997), h. 
(ghuluw). Mendamaikan antar kelompok manusia yang heterogen bukanlah suatu pekerjaan yang mudah dan simple. Namun ini tidak berarti mustahil bisa dilakukan.

\section{d. Mendakwahkan pemikiran Islam kontemporer}

Sebagaimana yang telah dipahami bahwa Islam adalah nama din (agama) yang diajarkan Nabi Muhammad, berpedoman pada kitab suci Al-quran yang diturunkan kedunia melalui wahyu Allah Subhanahu wata'ala dan dilengkapi dengan al-Hadits sebagai sumber kedua dalam Islam. Sementara itu istilah kontemporer diartikan pada waktu yang sama, semasa, sewaktu, pada masa kini, dewasa ini. ${ }^{24}$ Dengan demikian dapat dipahami secara bahasa Islam kontemporer berarti din (agama) yang diajarkan oleh Nabi Muhammad Shallahu 'alaihi wasallam pada masa lampau dan berkembang sampai saat ini.

Diantara pakar memberikan rumusan secara istilah bahwa Islam kontemporer adalah gagasan untuk mengkaji Islam sebagai nilai alternatif baik dalam perspektif interprestasi, tekstual maupun kajian kontekstual mengenai kemampuan Islam memberikan solusi baru kepada temuan-temuan di semua dimensi kehidupan dari masa lampau hingga sekarang. ${ }^{25}$ Maka dari rumusan ini terlihat ketika berbicara Islam kontemporer bermakna berbicara tentang gagasan atau pemikiran yang dilahirkan dari ajaran Islam sebagai agama yang memiliki nilai-nilai universal. Sehingga kemudian melahirkan pemikiran Islam kontemporer, yang dimaksudkan untuk menghadirkan Islam sebagai solusi ditengah kehidupan masyarakat sekaligus menjawab berbagai isuisu kontemporer sebagai tantangan dakwah Islam di era global ini. Pemikiran Islam kontemporer inilah yang harus didakwahkan, sehingga mampu memposisikan Islam itu sebagai ajaran yang universal dan rahmatan lil 'alamin. Inilah sesungguhnya hakikat dari dakwah Islam, yaitu kesungguhan dalam berusaha mengaktualisasikan fungsi kerisalahan yang diwariskan nabi Muhammad dan selanjutnya nilai-nilai risalah itu dapat dimanifestasikan sebagai sumber gagasan, sikap, perilaku atau cara hidup (way of life) bagi semua manusia.

Globalisasi sesuatu yang tidak bisa dielakkan dan menjadi jalan sejarah untuk disikapi dengan kearifan dan optimisme. Khususya seorang muslim sudah memiliki bekal atau pedoman (guidance) yang sempurna dalam menghadapai berbagai persoalan yang telah, sedang dan akan terjadi. Dari proses dialektika dan koneksitas era global

\footnotetext{
${ }^{24}$ Kamus Besar Bahasa Indonesia, h. 459.

25 Yatimin Abdullah, Studi Islam Kontemporer,(Jakarta: Amzah, 2006), h. 202
} 
ini, maka umat Islam dan khususnya lagi Islam sebagai sebuah agama dihadapkan dengan isu-isu dan problem kekinian (kontemporer). Oleh karenanya, suka tidak suka harus ada interpretasi baru terhadap ajaran Islam. Sehingga melahirkan ide atau pemikiran Islam kontemporer.

Secara umum dapat dikatakan bahwa ide atau gagasan pemikiran Islam kontemporer lahir dari upaya mempertemukan dua kutub yakni antara "tradisi dan modernitas" (al-turats wa al-hadatsah). Maka keberadaan dua sisi ini, tradisional dan modernitas ini menjadi faktor yang memunculkan kesadaran baru dalam melahirkan gagasan yang dapat merespon problematika kekinian. Selama ini ada terkesan bahwa pemikiran Islam tradisional memandang modernitas sebagai keanehan yang seharusnya tidak disentuh. Demi kelansungan konservatif sehingga ada sikap apriori terhadap kebaruan. Sementara pemikiran Islam modernis secara serampangan menabrak tradisi yang sudah kokoh dengan dalih perlunya pembaharuan pemikiran dan kemajuan. Dengan demikian muncul pertanyaan, apakah tradisi yang mesti disorot dengan sudut pandang modernitas ataukah modernitasnya yang mesti dilihat dengan kacamata tradisi, atau juga mungkinkah kedua sisi tersebut dikompromikan?.

Berbeda dengan Islam kontemporer melihat bahwa turats adalah prestasi sejarah, sementara hadatsah adalah realitas sejarah. Maka tidak bisa menekan turats apalagi menafikannya hanya demi pembaharuan, rasionalisasi atau modernisasi sebagaimana perspektif modernis selama ini. ${ }^{26}$ Tetapi tidak juga dengan serta merta segala yang muncul dari modernitas (hadatsah) akan ditolak atau disingkirkan. Meskipun disadari sepenuhnya bahwa modernitas memiliki kekurangan yang harus dikoreksi dan diluruskan, namun ia pun membawa banyak keuntungan terutama dari sisi perkembangan sains dan teknologi yang menjadi solusi problem kehidupan manusia abad ini. Oleh karena itu muncul kesadaran baru untuk membaca ulang secara krirtis warisan tradisi intelektual Islam masa lalu dan saat bersamaan melakukan filterisasi secara ketat terhadap modernitas. Sehingga kemudian meracik ramuan keduanya dalam upaya melahirkan ide atau gagasan yang lebih solutif dan up to date. Hasilnya bisa dilihat pada beberapa dasawarsa terakhir geliat pemikiran Islam makin dinamis dan menunjukkan trend yang baru. Dinamika perkembangan pemikiran ini dibuktikan lahirnya gagasan-gagasan akademik yang cemerlang dan karya-karya intelektual dalam menjawab tantangan kontemporer.

\footnotetext{
26 Muhammed Arkoun, Berbagai Pembacaan h. 120
} 
Islam adalah ajaran yang universal. Universalisme Islam dimaknai bahwa risalah Islam diperuntukkan untuk semua manusia tanpa memandang ras, suku, bangsa dan bahkan lapisan yang ada dalam masyarakat sekalipun. Oleh karena itu semua manusia dipandang sama, tidak ada yang merasa lebih baik. Tidak ada juga yang merasa lebih berhak menerima dan menjalankan risalah ini dari kelompok yang lain. Sehingga semua manusia harus melakukan ketundukan dan penyerahan secara totalitas kepada-Nya.

Al-Faruqi menyebutkan bahwa meskipun pada awalnya seseorang itu berada di dalam tubuh suatu bangsa, sekelompok bangsa atau hanya sekelompok individu. Hakikatnya ia adalah satu dalam arti bahwa ia meliputi seluruh manusia. Oleh karenanya, tatkala berbicara secara Islam, bukan lagi menyebutkan tata sosial Arab atau Turki, Iran atau Pakistan ataupun Malaysia, melainkan sudah menjadi satu yakni tata sosial Islam. Meskipun tata sosial tersebut berawal dari negeri atau kelompok tertentu dalam Islam. ${ }^{27}$ Sejatinya, risalah Islam adalah bentuk manifestasi kasih sayang Allah kepada semua manusia untuk menyelamatkan dari kegelapan kepada cahaya hidayah. Sebagaimana dalam makna firman-Nya disebutkan: "Dan tidak kami utus engkau (Muhammad), kecuali sebagai rahmah bagi seluruh alam” (Q.S.21;107).

Universalisme Islam menampakkan diri dalam berbagai manifestasi penting dan yang terbaik dalam ajaran-ajarannya. Ajaran-ajaran Islam yang meliputi sekuruh dimensi di antaranya mencakup aspek akidah, syari'ah, akhlak. Islam memberikan perhatiannya yang sangat besar terhadap persoalan utama kemanusiaan. Semua ini terbukti bahwa yang menjadi tujuan utama syariat (maqasid as-syariah) dalam Islam diperuntukka untuk menjaga aspek vital dalam hidup manusia yakni menjaga atau menjamin keselamatan agama, jasad, akal, keturunan, harta, dan kehormatan manusia. Selain itu, risalah Islam juga menampilkan nilai-nilai kemasyarakatan (social values) yang luhur, yang bisa dikatakan sebagai tujuan dasar syari'ah, yaitu keadilan, ukhuwah, takaful, kebebasan, dan kehormatan. ${ }^{28}$

Berangkat dari gambaran nilai-nilai universalitas Islam di atas, maka secara meyakinkan dapat dikatakan bahwa ajaran Islam sangat relevan sebagai ajaran bagi tatanan global. Akan tetapi memposisikan Islam dalam percaturan global bukan perkara yang gampang. Prinsip-prinsip ajaran Islam yang bersifat universal dapat dijadikan

\footnotetext{
27 Isma'il Raji al-Faruqi, Tauhid, terj. Rahmani Astuti, Bandung: Pustaka, 1988) h. 110

${ }^{28}$ Yusuf Qardhawi, Madkhal li al-Dirasat al-Islamiyyah, (Beirut: Dar al-Syuruq, 1993), h.61
} 
landasan bagi umat Islam. Oleh karena itu perlunya dihadirkan pemahaman yang tepat terhadap nash-nash sumber ajaran Islam tersebut. Meskipun adanya banyak perbedaan bahkan pertentangan dalam pemahaman nas-nash tersebut, akan tetapi perlu ditegaskan bahwa ada kesatuan prinsip dalam Islam yang bisa menaungi dan menyatukan semuanya yaitu kesatuan aqidah. Ini juga berarti bahwa Islam dan umatnya tidak hanya tetap bisa survive atau bertahan, lebih dari itu dengan segala kelebihan ajarannya mesti lebih memberikan kontribusi dan peran aktif.

Pandangan mereka yang selama ini apriori dan anti Islam, selalu mendiskreditkan bahwa Islam menolak globalisasi, penentang modernisasi. Umat Islam dilabeli sebagai manusia yang jauh dari spirit prulalisme dan anti toleransi. Sebetulnya klaim-klaim yang dialamatkan kepada Islam dan umatnya ini adalah sesuatu yang jauh dari kebenaran. Jika saja mereka mau membaca dan memahami nash-nash dari sumber ajaran Islam, maka spirit kebersamaan, toleransi, pengakuan eksitensi kemanusiaan, penghormatan terhadap hak asasi, semua nilai-nilaiini diabadikan secara jelas dan tegas dalam Islam. Bahkan nilai-nilai yang disebutkan di atas bukan hanya berada pada tataran teoritis tapi menjadi sesuatu yang aplikatif dalam praktek kehidupan sebagaimana yang langsung dicontohkan nabi Muhammad beserta generasi awalIslam. Dan contoh ini menjadi warisan yang harus dijalankan oleh umat Islam pada generasi kini dan mendatang. Kemajemukan dalam segala aspek kehidupan khusunya agama bagi umat Islam adalah sesuatu yang harus diyakini sebagai ketentuan Allah yang harus diterima. Prulalitas agama-agama adalah sebuah keniscayaan. Oleh karena itu, ajaran Islam melarang keras adanya unsur paksaan dalam menerima keyakinan atau memilih suatu agama apapun. Dalam konteks Indonesia, umat Islam selama ini sudah terbangun kesadaran bahwa pluralisme agama sebagai suatu yang tidak bisa dihindari. Sehingga kemudian mampu merawat nilai-nilai kebersamaan yang melahirkan sikap toleransi yang bertanggungjawab. Bukan toleransi yang dipaksakan dan kebablasan sehingga hilang jadiri agama masing-masing. Sikap seperti inilah yang dapat menghindari konflik dan perpecahan yang mengatsnamakan agama.

Oleh karenanya, terdapat tiga opsi bagi masyarakat Indonesia dalam menjawab prulalitas agama : pertama, adalah sikap menerima kehadiran kelompok agama lain atas dasar konsep hidup berdampingan secara damai. Dalam hal ini diperlukan sikap tidak saling mengganggu. Kedua, adalah mengembangkan kerjasama sosial keagamaan melalui berbagai kegiatan yang secara simbolik menunjukkan dan fungsional mendorong proses pengembangan kehidupan beragama yang rukun. Ketiga, adalah 
mencari, mengembangkan dan merumuskan titik temu agama dalam rangka menjawab problem tantangan dan keprihatinan umat manusia. ${ }^{29}$

Artinya ditegaskan kembali ini bahwa pluralisme tidak diorientasikan atau diarahkan dalam aspek yang menyangkut keyakinan ketuhanan atau teologis. Dengan kata lain tidak dimaknai kesamaan dalam keyakinan dan ibadah, karena dalam ajaran Islam segala sesuatu yang terkait dengan keyakinan dan pengabdian merupakan sesuatu yang sudah qoth'i dan tegas. Semua manusia diberikan kebebasan menjalankan keyakinannya, dan tidak dibolehkan satu komunitas melakukan pemaksanaan terhadap kelompok yang lain

Di antara pemikir Islam menyebutkan bahwa satu hal yang tidak dapat dinafikan sebagai fakta historis yaitu istilah atau konsep pluralisme atau dalam bahasa Arabnya, al- taaddudiyyah bukan sesuatu yang populer bahkan tidak terpakai dikalangan para cendekiawan Islam terdahulu. Baru setelah terjadi kemajuan pesat transformasi dan era globalisasi pada dekade abad ke 20 istilah prulalisme makin mengemuka. Tentu ini tidak bisa terlepas dari kebijakan internasional Barat yang memasuki sebuah fase yang dijuluki sebagai marhalat al-ijtiyah (fase pembinasaan). Ini ditandai dengan bagaimana propaganda Barat dengan segala caranya untuk menawarkan ideologi modernnya yang dianggap paling universal, seperti demokrasi, pluralisme, HAM, pasar bebas dan sebagainya. Barat dengan bangga menjajakan dagangannya dengan penuh keyakinan sekaligus dengan unsur penekanan Suatu kebijakan yang telah dikemas atas dasar superioritas ras dan kultur Barat, serta peremehan atau penghinaan terhadap segala sesuatu yang bukan Barat, Islam khususnya. Berbagai tuduhan yang menyakitkan diarahkan kepada Islam seperti tidak toleran, anti demokrasi, fundamentalis, sektarian dan sebagainya. Maka sebagai respons terhadap perkembangan politis baru ini, masalah pluralisme mulai mencuat dan menjadi concern kalangan cerdik-cendekia Islam yang pada gilirannya menjadi komoditas paling laku di pasar pemikiran Arab Islam kontemporer. ${ }^{30}$

Begitu pula halnya dalam konteks libelarisasi atau Islam liberal. Dalam ajaran Islam sudah sangat jelas, bahwa ada ajaran Islam yang bersifat qath ' $i$, yang tidak boleh berubah seiring dengan perkembangan zaman. Atau seorang muslim harus menerimanya syariat tersebut tanpa alasan apapun. Namun terdapat pula ajaran-ajaran

\footnotetext{
29 Mursyid Ali, Problema Komunikasi Antar Umat Beragama, (Jakarta :Balitbang. 2000), h. 39

${ }^{30}$ Anis Malik Thoha, Tren Pluralisme, h. 180-181
} 
Islam yang memberikan ruang atau pintu bagi seorang muslim menggunakan pemikiran (ijtihad) yang tetap trbimbing dengan landasan al-Qur'an dan Sunnah. Celakanya para pemikir liberal Islam ini mencoba untuk tetap memasuki wilayah-wilayah yang sudah final (tauqifi) atau tidak diperkenankan ijtihad di aspek tersebut. Ini terkesan ingin merombak tatanan atau ajaran Islam yang sudah sempurna. Misalnya pembenaran pernikahan atau hidup dalam satu rumah tangga yang berbeda agama. Ini bermakna meliberalkan Alquran atau menggugat kebenaran al-Quran itu sendiri. Ini sebuah tantangan bagi tokoh-tokoh Islam yang masih memiliki kepedulian untuk dapat menjaga orisinalitas dan kebenaran hakiki ajaran Islam dari segala upaya pembusukan dari dalam tubuh umat Islam sendiri.

Begitu pula halnya dengan isu yang berhubungan dengan radikalisme dan terorisme. Sesungguhnya tindakan dan perilaku kekerasan yang dipertontonkan segelintir orang dengan ciri khas dan atribut-atribut Islam, bukanlah sesuatu yang mengembirakan dan menguntungkan, apalagi kekerasan dan teror itu mengatas namakan Islam. Justru perilaku seperti di atas ini dapat merendahkan ketinggian Islam. Bahkan bagi pihak Barat ini dijadikan momentum yang pas bagi merka untuk menyudutkan Islam sebagai biang radikal dan teror di semua belahan dunia.

Yusuf al-Qardhawi menegaskan bahwa munculnya radikalisme keagamaan didorong oleh faktor minimnya pemahaman yang benar dan mendalam atas esensi ajaran agama Islam itu sendiri, di mana Islam hanya dipahami secara dangkal dan parsial. ${ }^{31}$ Padahal sejatinya bahwa Islam adalah agama damai sebagaimana makna terminologi Islam itu sendiri adalah damai dan selamat. Tidak akan diketemukan dalam Islam baik secara norma maupun pada sejarah kenabian pesan-pesaan yang merangsang dan mentolerir praktek-praktek teroris dan radikalis. Perdamaian dan penjagaan keselamatan diri orang lain bahkan menjadi ukuran atau barometer keimanan seorang muslim. Perdamaian dan kasih sayang dalam Islam bukan hanya norma tanpa fakta. Sejarah membuktikan apa yang telah yang diteladankan oleh panutan umat Islam nabi Muhammad beserta para pengikutnya terdahulu. Salah satu bukti konkrit yang tetap akan dikenang sampai hari ini dan tercatat dalam sejarah dunia adalah lahirnya Piagam Madinah (Constitution of Madinah). Siapapun, ras dan agama apapun akan damai bersama Islam. Oleh karena itu, bukti historis dan pemahaman terhadap Islam seperti ini harus selalu dimunculkan ke permukaan, sehingga menjadi bantahan terhadap

\footnotetext{
${ }^{31}$ Yusuf Qardhawi, as-Shahwah al-Islamiyyah, h. 59
} 
tuduhan Barat bahwa Islam adalah agama yang mendorong lahirnya radikalisme dan terorisme. Islam dihadirkan untuk menjadi rahmat dan keselamatan bagi siapapun. Inilah hakikat Islam sebagai rahmatan lil alamin.

\section{PENUTUP}

Globalisasi adalah suatu era yang menjadikan semua manusia yang tinggal di planet bumi ini menjadi saling ketergantungan, saling mempengaruhi dan hampir tanpa batas antar individu, masyarkat bahkan dunia yang lain atau dengan istilah "dunia tanpa batas". Tentu saja konsekuensinya bermunculan dampak-dampak dari globalisasi, baik dampak positif maupun dampak yang negatif. Kemudahan beraktifitas, lancarnya berkomunikasi, efektifitas dan efisiensi waktu dengan dukungan transportasi yang cepat, semua ini menjadi sebagian kecil pengaruh positif globalisasi dan modernisasi. Selain memberikan banyak keuntungan bagi manusia, namun globalisasi turut mendorong munculnya banyak penyimpangan dan disoriemtasi nilai dalam kehidupan manusia. Menjelmanya praktek-praktek kehidupan individualistik, materialistik dan hedonistik dan sebagainya. Manusia juga mengalami apa yang disebut dengan degradasi moral, kekeringan dan kehampaan spiritual yang melahirkan beragamnya penyakit atau gangguan kejiwaan.

Islam adalah agama yang Allah pilih untuk dijadikan sebagai manhaj al-hayat atau acuan nilai dan tatanan kehidupan yang sempurna, syamil, kamil, tawazun dan integrated. Dengan segala kesempurnaannya, tata nilai Islam harus mampu dihadirkan sebagai solusi di era kontemporer ini karena sifatnya yang universal. Sehingga Islam akan menjadi warna di tengah kehidupan masyarakat dan peradaban global. Terlebih lagi bermunculan isu-isu kontemporer yang bersinggungan langsung dengan agama dan nilai-nilai yang ada di dalamnya. Di antaranya prulalisme agama, liberalisme agama, terorisme-radikalisme dan sebagainya. Sebagai bagian dari agama global sudah tentu Islam tidak bisa terlepas atau pasti terseret dari isu-isu tersebut, baik sebagai subjek maupun objek dari problematika kekinian.

Dengan ijtihad yang mampu meramu kelebihan tradisi (turats) dan keunggulan (hadatsah) maka pemahaman terhadap Islam dan pemikirannya bisa semakin dinamis dan berkembang. Ini bermakna bahwa bukan hanya persoalan atau problematika kontemporer saja yang terus mengalami perubahan dan komplek. Namun pemahaman terhadap warisan Islam harus terus digali secara mendalam agar mampu adaptif dengan persoalan dan realitas yang terjadi. Sebagaimana karakteristik atau watak dari 
ajaran Islam itu sendiri yang luwes, lentur dan cocok untuk segala zaman. Sehingga pemikiran Islam kontemporer menjadi hajat yang tidak terelakkan untuk melahirkan peradaban manusia yang lebih baik. Oleh karenanya, concern yang serius dan pemahaman yang utuh terhadap ajaran-ajaran Islam yang universal merupakan keniscayaan agar Islam bisa memberi suatu konstribusi yang berarti bagi persoalanpersoalan kemanusiaan. Inilah hakikat mendakwahkan pemikiran Islam kontemporer. Sehingga Islam betul-betul dirasakan sebagai rahmatan lil 'alamin.

\section{REFERENSI}

Abdullah, Yatimin. 2006, Studi Islam Kontemporer, Jakarta: Amzah.

Al-Attas, Syed Muhammad Naquib. 1993 Islam and Secularism, Kuala Lumpur: ISTAC.

Ali, Mursyid. 2000, Problema Komunikasi Antar Umat Beragama, Jakarta :Balitbang.

Azizy, A. Qodri. 2004, Melawan Globalisasi; Reinterpretasi Ajaran Islam Persiapan SDM dan Terciptanya Masyarakat Madani, Yogyakarta: Pustaka Pelajar.

Arkoun, Mohammed. 1997, Berbagai Pembacaan al-Qur'an, terj. Machasin, Jakarta: INIS.

Baiquni, Achmad. 1995, Al-Qur'an; Ilmu Pengetahuan dan Teknologi, Yogyakarta: Dana Bhakti Prima Yasa.

Bryne, Peter. 1995, Prolegomena to Religious Pluralism, London: Macmillan Press Ltd.

Departemen Pendidikan dan Kebudayaan, 1995, Kamus besar Bahasa Indonesia, Jakarta: Balai Pustaka

Al-Faruqi, Isma'il Raji. 1988, Tauhid, terj. Rahmani Astuti, Bandung: Pustaka.

Esposito, John L.2003, Unholy War: Teror atas Nama Islam, Yogyakarta: Ikon.

Giddens, A. 1990. The Consequences of Modernity. Cambridge: Polity Press

Husaini, Adian. 2006, Liberalisasi Islam di Indonesia; Fakta dan Data, (T.K: Dewan Da'wah Islamiah Indonesia.

Kahmad, Dadang. 2000, Sosiologi Agama, Bandung: Remaja Rosdakarya.

Madjid, Nurcholis dkk, 2005, Fiqh Lintas Agama, Jakarta: Paramadina.

Maksum, Ali. 2002, Tasawuf Sebagai Pembebasan Manusia Moderen: Telaah Signifikansi Konsep Tradisionalisme Sayyid Husein Nasr, Surabaya: Pustaka Pelajar.

Mulkhan, Abdul Munir. 2002, Ajaran dan Jalan Kematian Syekh Siti Jenar, Yogyakarta: Kreasi Wacana. .

Qardhawi, Yusuf. 1993, Madkhal li al-Dirasat al-Islamiyyah, Beirut: Dar al-Syuruq. 2001, as-Shahwah al-Islamiyyah bayna al-Juhud wa at-Tatharruf, cet. ke-1, Kairo: Dar asy-Syuruq. 
Shihab, Alwi. 1997, Islam Inklusif: Menuju Sikap Terbuka dalam Beragama, Bandung: Mizan Pustaka.

Scholte, J.A. 2005, Globalization : A Critical Introduction. 2ndEdition, London: Red Globe Press.

Subkhan, Imam. 2007, Hiruk Pikuk Wacana Pluralisme di Yogya, Yogyakarta: Kanisius.

Rahman, Fazlur. 1979, Islam, Chicago: University of Chicago Press.

Thoha, Anis Malik. 2005, Tren Pluralisme Agama, Tinjauan Kritis (Cet.I), Jakarta:Gema Insani

Waters, M. 1995. Globalization. 2ndEdition. Taylor and Francis Group. London

Zarkasyi, Hamid Fahmi. 2008, Liberalisasi Pemikiran Islam, Gerakan Bersama Missionaris, Orientalis dan Kolonialis, Gontor: CIOS-ISID.

Majalah GATRA, edisi 21 Desember 2002.

Harian Kompas edisi 18 November 2002.

http://islamlib.com 